\title{
A Kinetic Measurement of Red Cell Deformability: A Modified Micropipette Aspiration Technique
}

\author{
Takeshi Shiga, Nobuji Maeda, Takeo Suda, Kazunori Kon, \\ Misuzu SeKIYA, and Syoten OKA* \\ Department of Physiology, Medical School, Ehime University, Ehime, 791-02 Japan \\ *National Cardiovascular Center, Research Institute, Osaka, 565 Japan
}

\begin{abstract}
A kinetic measurement of the red cell deformability is developed, modifying the micropipette aspiration technique of BRAASCH (1971). The sedimented human red cells on a slide-glass are individually aspirated into a micropipette by negative pressure $(\triangle P)$, and the decreasing "velocity (v)" of the applied electric current, due to the aspirating cell, is taken as a measure of the "easiness" of the cell to enter into the small orifice of the micropipette (inner diameter, $2 R \simeq 3 \mu \mathrm{m}$ ). An empirical relation, $v \propto\left(\pi R^{2}\right) \cdot(\Delta P) \cdot$ ("deformability"), is obtained.

In order to test the validity of the method, some factors influencing the deformability are studied: $i$. e., the "velocity" decreases as lowering temperature; the "velocity" of the glutaraldehyde-pretreated cells and of both in vivo and in vitro aged cells decreases. Therefore, the parameter, "velocity (v)," reflects the deformability well. In addition, if a few assumptions could be allowed, $v$ would be related to the Young's modulus of the membrane.
\end{abstract}

The importance of the red cell deformability in the blood circulation has been frequently discussed (ChiEN, 1975; Schmid-Schönbein, 1976; Stoltz and VigneRON, 1976), i. e., (i) the red cells must be deformed in order to pass through a capillary narrower than their diameter and (ii) the red cells are deformed under high shear stress so as to reduce the blood viscosity. Therefore, a number of techniques have been developed to determine deformability. Some of them need complicated apparatus and/or require elaborate manipulation. Further, it is recognized that the physical meaning of the determined parameters sometimes differs from one method to another because of the complexity of the subject. Thus, at the present stage it is necessary that a newly developed method be tested in order to analyze the factors affecting red cell deformability.

Among the various methods, the micropipette aspiration technique (MITCHISON and SWANN, 1954) has been successfully applied to the red cells by RAND and Burton (1964) and by JAY (1973), then refined by Evans (1973). Their methods

Received for publication April 13, 1979

志賀 健, 前田信治, 須田武雄, 昆 和典, 関谷美鈴, 岡 小天 
analyze the relation between the applied negative pressure and the cell deformation, thus they are suitable for determining mainly membrane viscoelasticity (EvANS and LA CELLE, 1975).

On the other hand, BRAASCH (1971) has introduced a simple micropipette aspiration technique by which the "easiness" of the cell aspiration and the passage time can be visualized on the oscilloscope. Later, SCHLICK and SCHMID-SCHÖNBEIN (1975) made a one-hole filtration apparatus, combining the classic filtration technique of TEITEL (1967) and the method of BRAASCH (1971), which gives a practically useful but physically complex parameter of the "deformability." An additional feature of these micropipette techniques is the ability to determine the parameters for the individual red cells under microscope, allowing the statistical distribution of the parameters to be obtained.

In the present paper, a modified micropipette aspiration technique will be described. It is essentially an extension of the Braasch's method, but gives a kinetic measure reflecting the red cell properties. In order to test the validity of the technique, some additional experiments were carried out, e.g., the effects of temperature and cell hardening and the influences of cell aging. Further, the measurement expressing the "easiness to deform" may be related to the Young's modulus of the membrane, if a few assumptions are accepted.

\section{MATERIALS AND METHODS}

Preparation of red cells with various properties. Fresh cells: heparinized, fresh blood was collected by a venipuncture and kept at $0^{\circ} \mathrm{C}$. During storage, the ATP content did not decrease appreciably within $4 \mathrm{hr}$.

Washed cells: after centrifugation of the fresh blood, the plasma and the buffy coats were removed, then the cells were washed twice with 20 volumes of an isotonic solution made up of a mixture of $100 \mathrm{vol}$. of isotonic $\mathrm{NaCl}, 50 \mathrm{vol}$. of isotonic sodium phosphate buffer and 5 vol. of isotonic potassium phosphate buffer (final $\mathrm{pH}$ was adjusted to 7.40 at $37^{\circ} \mathrm{C}$ ), containing $0.1 \%$ glucose.

Hardened cells: the washed cells were suspended in isotonic solution containing glutaraldehyde of 0.01 to $2.0 \%$ for $30 \mathrm{~min}$ at $0^{\circ} \mathrm{C}$, then the treated cells were washed 3 times with 20 volumes of isotonic solution.

Preserved cells: acid-citrate-dextrose $(\mathrm{ACD})$ blood, stored for 16 days at $4^{\circ} \mathrm{C}$, was used.

Young and old cells: the density gradient centrifugation with Dextran T-40 was performed for the fractionation of young and old cells, and the top and the bottom layers were collected as the young and old cell fractions, respectively (ABRAHAM et al., 1975). The cells were washed 3 times in order to remove dextran, and resuspended in their own plasma. The per cent-fraction was expressed on the basis of the hemoglobin content, determined by $\mathrm{CN}$-methemoglobin method (VAN ASSENDELFT, 1970). 
Determination of chemical and functional properties of red cells. ATP, ADP and AMP contents were determined by liquid chromatography using a Hitachi model 634A chromatograph; 2, 3-diphosphoglycerate (2, 3-DPG) content was measured by the method of MAEDA et al. (1971); the intracellular $\mathrm{pH}\left(\mathrm{pH}_{\mathrm{i}}\right)$ was measured by a modified method of ENOKI et al. (1972) on the hemolysate obtained by freezing and thawing using a Radiometer $\mathrm{pH}$ meter (model PHM-64, with a capillary electrode); the oxygen equilibrium curve was recorded by the method of ImaI et al. (1970) using a Union SM-401 spectrophotometer. The osmotic fragility was measured by the continuous dilution method of MAEDA et al. (1977): the membrane "fluidity" was monitored by the fatty acid spin labels (HubBELL and MCCONNELl, 1971; AxEL, 1976; SHIGA et al., 1977), 2-(10-carboxydecyl)-2-hexyland 2-(14-carboxytetradecyl)-2-ethyl-4,4-dimethyl-3-oxazolidinyloxyl (denoted as $\mathrm{I}(5,10)$ and $\mathrm{I}(1,14)$, respectively), using a Varian E-3 EPR spectrometer.

Micropipette aspiration technique. In principle, individual red cells dispersed on a slide glass (Hemacytometer, Bürker-Türk type, 1/10 mm depth) were aspirated into a micropipette by an appropriate negative pressure. Simultaneously, an electric current was applied to monitor the movement of the cells around the micropipette tip portion. When the cell occupied the tip portion, the electric resistance increased and the electric current decreased. The time course of the current change was recorded (Fig. 1).

Micropipette: the micropipettes (i.d. of orifice $\simeq 3 \mu \mathrm{m}$ ) were made from pyrex glass capillaries (o.d. $=1.5 \mathrm{~mm}$ ) using a glass electrode puller (Narishige Sci. Co.). The micropipette was connected to a moving reservoir by a tubing filled with isotonic solution as to give a desired negative pressure, and was handled by a micromanipulator.

Electric circuit: a dry battery (6 V) was connected to calomel electrodes, then to agar bridges containing isotonic $\mathrm{NaCl}$, which were immersed in the reser-

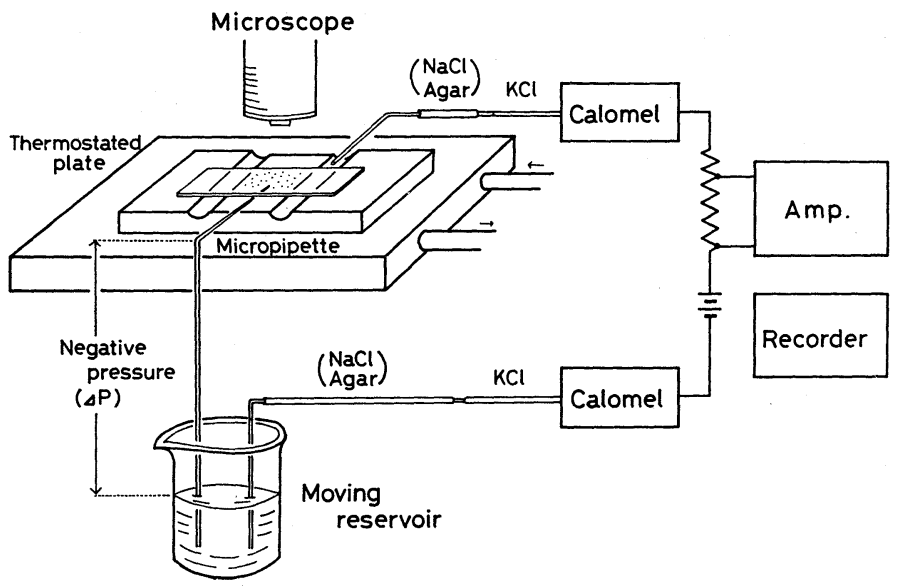

Fig. 1. Scheme of the apparatus (see text for details). 
voirs of isotonic solution. The fixed reservoir was connected with the cell suspension on the slide glass by a tubing filled with isotonic solution. The moving reservoir was connected to the micropipette. The electric current was dependent on the i.d. of the micropipette orifice, e.g., an i.d. of $3 \mu \mathrm{m}$ gave about $0.3 \mu \mathrm{A}$. For the recording, a DC amplifier (Ohkura Electr. Co.) and a pen-oscillograph (Watanabe Sokki Co.) were employed. The response of the system was tested by applying saw-tooth electric wave.

Temperature control: a plate, thermostated by circulating water from a temperature controlled water bath, was placed on the stage of the microscope. A thermocouple was attached on the slide glass.

Operation: the red cell suspension was dropped on the thermostated slide glass, then the micropipette was settled and a cover glass was mounted in order to prevent evaporation. The micropipette was handled by a micromanipulator and the pipette orifice was contacted to the rim of the sedimented red cell. Applying an appropriate pressure, the cell was aspirated into the micropipette. When the tip portion was completely occupied by the cell, the electric current decreased, e.g., from 0.30 to $0.26 \mu \mathrm{A}$.

Time course of the current change and the cell deformation. As the cell aspiration proceeded, the current decreased and the cell became deformed. The typical recorder trace and the schematic view of the cell shape are shown in Fig. 2.

Four periods of current change were distinguished.

1) The first period $\left(0<t<t_{1}\right.$, in Fig. 2) was within $1 / 20 \mathrm{sec}$, where the current began to fall.

2) The second period $\left(t_{1}<t<t_{2}\right)$ lasted for $1 / 5$ to $1 / 25 \mathrm{sec}$, depending on the i.d. of the pipette orifice and on the negative pressure, where the current decreased apparently linearly with time and the change was maximal $(60-80 \%$ of total). At the end of this period, the cell suddenly deformed to a hemispheric shape.

3) During the third period $\left(t_{2}<t<t_{3}\right)$, the current slowly decreased, and reached a minimal value. The cell could be held by adjusting the pressure, and its

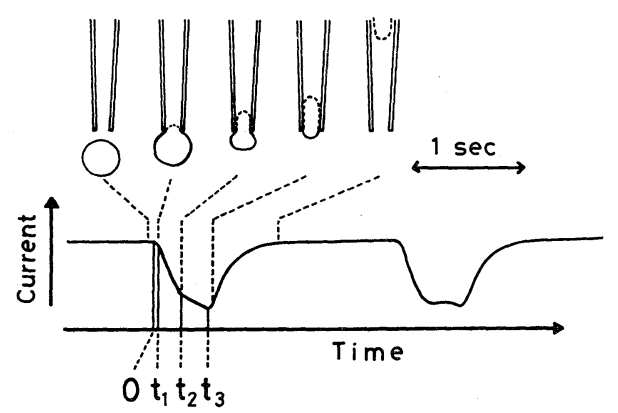

Fig. 2. Time course of the electric current changes and the red cell shapes. Top: schemes of the cell shape changes. Bottom: recorder trace of the electric current change. 
shape in the outside and inside of pipette was hemispheric and finger-like, respectively.

4) In the last period $\left(t>t_{3}\right)$, the cell was detached from the narrow tip portion, the current often showed a tip, then returned to the initial value. The completely detached cell showed a normal discocyte.

Two parameters expressing the "easiness" of the deformation and passage can be quantified. (i) The time required to pass through the narrow tip portion can be directly determined between the points of $50 \%$ current changes (denoted as "passage time"). (ii) Another parameter is the velocity of the current decrease during the second period, since the current changes almost linearly with time for a wide range of the negative pressure (denoted as "velocity").

These parameters may be obtained from the first derivative curve, using a differential converter as described previously (SHIGA et al., 1971), i.e., the minimal peak height represents the maximal velocity and the time between the minimal and maximal peaks may be approximated to the passage time.

\section{RESULTS}

1. Characteristics of the parameter, "velocity (v)"

a) Two parameters, "velocity" and "passage time," were obtained for individual washed cells from the recorder traces (as shown in Fig. 2). The statistical distributions of both parameters were Gaussian, and the correlation coefficient $(|r|)$ of more than 0.7 was obtained.

b) A linear relation between the velocity and the negative pressure $(\Delta P)$ was obtained (Fig. 3). The extrapolated line passed the origin. However, if the pressure was too small, the cell could not be aspirated; and when the pressure was too large, the velocity exceeded the response time of the amplifier. Therefore, the pressure should be varied within a certain range, depending on the size of the

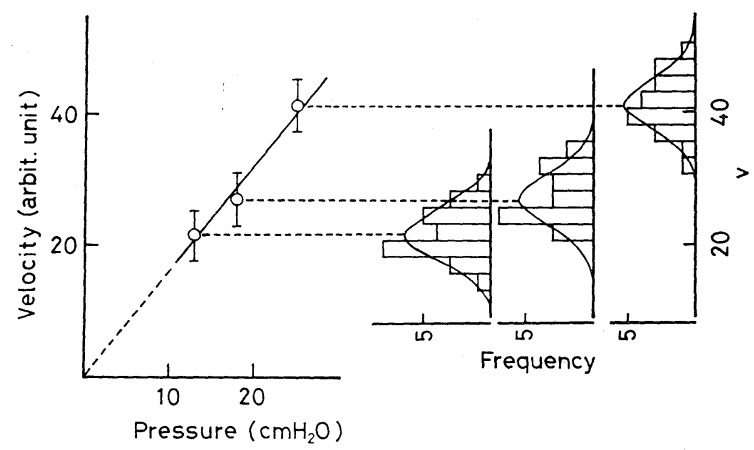

Fig. 3. The relation between the negative pressure and the "velocity." The "velocity" is expressed by arbitrary unit. The simulated Gaussian curves, using the observed mean and standard deviation, are shown together with the observed distributions. 
micropipette orifice, e.g., for an orifice with an i.d. of $3 \mu \mathrm{m}$, the pressure could be varied between 5 and $20 \mathrm{cmH}_{2} \mathrm{O}$. Such linear relation was always obtained between the negative pressure and the velocity (v), i.e., $v \propto(\Delta P) \cdot(" d e f$ "). The term "def" depended on the properties of individual cells and must be related to the cell deformability.

In contrast, no simple relation could be seen between the pressure and the passage time.

c) A linear relation was also obtained between the area of the micropipette orifice and the velocity, applying the same pressure (Table 1). The values of $v /$ (area) were fairly constant, thus $v \propto\left(\pi R^{2}\right) \cdot$ ("def"). However, when the i.d. of the orifice was too small (e.g., less than $2 \mu \mathrm{m}$ ), the pressure above $25 \mathrm{~cm} \mathrm{H}_{2} \mathrm{O}$ was required and the red cells often adhered to the tip or were broken, as described by RAND (1964). Conversely, if the i.d. was too large $(>4.5 \mu \mathrm{m})$, the current changes became too fast and exceeded the response time of the recording system.

Table 1. Relation between the area of micropipette orifice and the "velocity."

\begin{tabular}{ccc}
\hline Area $^{\mathrm{a}}$ & "Velocity" & "Velocity"/area \\
\hline 0.26 & $0.843 \pm 0.146$ & 3.242 \\
0.30 & $0.878 \pm 0.131$ & 2.927 \\
0.30 & $1.030 \pm 0.111$ & 3.433 \\
0.31 & $0.987 \pm 0.067$ & 3.184 \\
0.36 & $1.338 \pm 0.256$ & 3.717 \\
0.37 & $1.299 \pm 0.126$ & 3.511 \\
& & (Mean 3.336 \pm 0.277$)$ \\
\hline
\end{tabular}

a Expressed by the electric current in the absence of red cells; the values must be directly proportional to the area of the micropipette orifice used, thus they are relative values.

b Normalized, relative values of the "velocity," measured at $33^{\circ} \mathrm{C}$.

No rational relation between the sizes of the pipette orifice and the passage times was obtained.

d) When negative pressure and the size of the micropipette orifice are suitably adjusted, the velocity $(v)$ of the current decrease due to the entering red cell can be expressed by the following empirical equation:

$$
v \propto\left(\pi R^{2}\right) \cdot(\Delta P) \cdot(\text { “def") }
$$

The individual "def" can be represented by taking the $v$, at constant $\Delta P$ and $\pi R^{2}$, i.e., using the same micropipette and the same negative pressure. For a comparison of the different red cell specimens, one can use the ratios of the averaged $v$ 's as the relative measure of the deformability, i.e., $\bar{v}_{1}: \bar{v}_{2}: \bar{v}_{3}: \ldots \ldots$

\section{Effect of the glutaraldehyde pretreatment}

The velocity considerably decreased as the concentration of glutaraldehyde for the pretreatment was increased (Table 2). In this case, a micropipette with 
Table 2. The "velocity" and "passage time" of the glutaraldehyde pretreated red cells (at $34^{\circ} \mathrm{C}$ ).

\begin{tabular}{lccc}
\hline$\%$ glutaraldehyde & 0 & 0.01 & 0.02 \\
\hline "Velocity"a & $1.00 \pm 0.23$ & $0.41 \pm 0.07$ & $0.27 \pm 0.09$ \\
"Passage time"a & $1.00 \pm 0.35$ & $14.24 \pm 11.31$ & $-{ }^{\mathrm{b}}$ \\
\hline
\end{tabular}

a The values are normalized.

b The cells often adhere around the micropipette tip, thus the passage time cannot be measured.

a larger orifice (i.d. $\simeq 4 \mu \mathrm{m}$ ) was used, but the cells pretreated with $0.03 \%$ glutaraldehyde could not enter the micropipette even at $30 \mathrm{cmH}_{2} \mathrm{O}$ and were never deformed. The $0.02 \%$ glutaraldehyde pretreated cells often adhered around the tip portion, thus a stroke of back pressure (positive pressure) was needed to remove the cells. Therefore, the velocity could be determined for all the cells but not the passage time.

Comparing the untreated and $0.01 \%$ glutaraldehyde pretreated cells for two parameters, the relative velocities decreased from 1.00 to 0.41 by the pretreatment, while the relative passage times were prolonged considerably from 1.0 to 14.2 , and the standard deviation became large for the pretreated cells. This fact demonstrated that the passage times were highly dependent on the hardness of the cell membrane, as described by MEL and YeE (1975).

\section{Effect of temperature}

The velocities at various temperatures were compared for the same blood sample employing the same micropipette at the same pressure (Table 3). As

Table 3. Effect of temperature on the velocity and passage time.

\begin{tabular}{ccc}
\hline $\begin{array}{c}\text { Temperature } \\
\left({ }^{\circ} \mathrm{C}\right)\end{array}$ & Velocity $^{\mathrm{a}}$ & Passage time $^{\mathrm{a}}$ \\
\hline 37 & $1.00 \pm 0.16$ & $1.00 \pm 0.16$ \\
31 & $0.80 \pm 0.08$ & $1.40 \pm 0.34$ \\
25 & $0.53 \pm 0.05$ & $2.22 \pm 0.44$ \\
24 & $0.50 \pm 0.04$ & $3.10 \pm 0.84$ \\
14 & $0.44 \pm 0.06$ & $4.20 \pm 1.12$ \\
12 & $0.40 \pm 0.07$ & $6.98 \pm 2.59$ \\
\hline
\end{tabular}

a The values are normalized.

temperature was lowered, the velocities were reduced and the passage times prolonged, i.e., the cells became harder. The double reciprocals of the velocities and temperature were linear (Fig. 4). No distinct temperature break was observed within the experimental error between 11 and $37^{\circ} \mathrm{C}$.

In contrast, no simple correlation could be obtained between the passage time and temperature. 


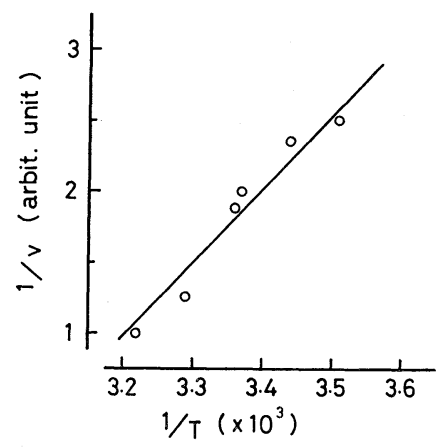

Fig. 4. The relation between $1 / T$ and $1 /$ "velocity." The values of 1 /"velocity" are normalized.

\section{Other factors affecting the red cell properties}

In order to test the applicability of the technique, a few experiments were carried out.

a) Effect of the plasma proteins: the washed cells were resuspended in the heparinized plasma, serum and isotonic solution, respectively. As far as analyzed by the velocities and the passage times, similar values were obtained regardless of the medium. The cells in plasma formed the rouleaux, i.e., the state of the membrane surface might be altered, but no difference in velocity was observed.

b) Effect of in vivo aging of red cells: the fractionated young and old cells were compared (Table 4), together with the biochemical and functional properties. The young cells were aspirated more easily than the old cells. Further, the oxygen affinity of the old cells increased, probably due to decreased 2, 3-DPG content.

c) Effect of blood preservation: the ACD blood (stored for 16 days at $4^{\circ} \mathrm{C}$ ) was compared with the fresh blood of the same person (Table 5). It was obvious that the preserved cells were aspirated more slowly than the fresh cells. However, since the preserved cells were echinocytes, the difference could be due to the shape change, although the decreased deformability of the preserved cells has been established (WEED et al., 1969; LA CELLE, 1969; WEED, 1970).

\section{DISCUSSION}

Basic character of the "velocity" measurement. The present method is essentially an extension of BRAASCH's method (1971) and similar to that of SCHLICK and SCHMID-SCHÖNBEIN (1975), except (i) the micropipette is handled by a micromanipulator in order to aspirate the individual cells uniaxially from the rim portion of the cell and (ii) the time course of current change is used for obtaining the parameter expressing the deformability.

The results of the "velocity" measurements can be summarized as follows: (i) the velocity is directly proportional to the applied negative pressure and to the 
Table 4. Comparison between the young and old red cells.

\begin{tabular}{|c|c|c|c|}
\hline & Young cells & Old cells & \\
\hline "Velocity" & $1.00 \pm 0.14$ & $0.75 \pm 0.12$ & Normalized values, at $33^{\circ} \mathrm{C}$ \\
\hline Fraction $\%$ & 10.3 & 7.8 & $\begin{array}{l}\% \text { of total, on the basis of } \mathrm{Hb} \\
\text { concentration }\end{array}$ \\
\hline $\mathrm{Hb}$ concentration & $4.62 \mathrm{~mm}$ & $5.77 \mathrm{~mm}$ & Per liter of packed cells \\
\hline $\mathrm{MCH}$ & $32.3 \mathrm{pg}$ & $33.9 \mathrm{pg}$ & \\
\hline $\mathrm{MCV}$ & $109 \mu \mathrm{m}^{3}$ & $91 \mu \mathrm{m}^{3}$ & \\
\hline Membrane fluidity $\left(\tau_{c}\right)^{a}$ & $2.88 \times 10^{-9} \mathrm{sec}$ & $3.07 \times 10^{-9} \mathrm{sec}$ & Spin label I $(1,14)$, at $24^{\circ} \mathrm{C}$ \\
\hline Membrane fluidity $\left(\tau_{\mathrm{c}}\right)$ & $2.44 \times 10^{-9} \mathrm{sec}$ & $2.56 \times 10^{-9} \mathrm{sec}$ & Spin label I $(1,14)$, at $39^{\circ} \mathrm{C}$ \\
\hline Membrane fluidity $(S)^{\mathrm{b}}$ & 0.620 & 0.639 & Spin label I $(5,10)$, at $24^{\circ} \mathrm{C}$ \\
\hline Membrane fluidity $(S)$ & 0.516 & 0.518 & Spin label I $(5,10)$, at $39^{\circ} \mathrm{C}$ \\
\hline $\mathrm{O}_{2}$ affinity $\left(P_{50}\right)^{\mathrm{c}}$ & $25.6 \mathrm{mmHg}$ & $20.4 \mathrm{mmHg}$ & $\mathrm{CO}_{2}$-depleted, at $37^{\circ} \mathrm{C}$ \\
\hline$\overline{\mathrm{ATP}^{\mathrm{d}}}$ & $0.899 \mathrm{~mm}$ & $0.713 \mathrm{~mm}$ & Per liter of packed cells \\
\hline ADP & $0.119 \mathrm{~mm}$ & $0.195 \mathrm{~mm}$ & Per liter of packed cells \\
\hline AMP & $0.018 \mathrm{~mm}$ & $0.060 \mathrm{~mm}$ & Per liter of packed cells \\
\hline 2, 3-DPG & $5.22 \mathrm{mM}$ & $4.06 \mathrm{~mm}$ & Per liter of packed cells \\
\hline $\mathrm{pH}_{\mathrm{i}}{ }^{\mathrm{e}}$ & 7.17 & 7.09 & At $37^{\circ} \mathrm{C}, \mathrm{pH}$ in red cell \\
\hline
\end{tabular}

a The correlation time $\left(\tau_{\mathrm{c}}\right)$ was calculated according to STONE et al. (1965) and ERNANDEZ et al. (1976).

b The order parameter $(S)$ was calculated according to HubBell and MCCONNELL (1971) and HeGNer et al. (1973).

c The oxygenation curve was recorded automatically by the method of IMAI et al. (1970). $\quad P_{50}$ of the blood (taken from T. S.) suspended in the same solution was always about $24 \mathrm{mmHg}$ at $\mathrm{pH}_{\mathrm{i}} 7.20$ (cf. Table 5).

d The ATP content of this particular red cells (taken from T. S.) was always smaller than the others.

e Intracellular $\mathrm{pH}$, measured just after the cell fractionation. During $\boldsymbol{P}_{50}$ measurement, $\mathrm{pH}_{i}$ was 7.17 for both samples, being suspended in the isotonic solution ( $\mathrm{pH} 7.36$ ).

area of the micropipette orifice, (ii) the velocities of the individual cells (of the same blood) differ but follow the Gaussian distribution, (iii) the double reciprocal plot of the velocities and temperature gives a straight line, (iv) the velocity decreases by the glutaraldehyde pretreatment, (v) the velocity decreases by in vivo and in vitro aging, and (vi) the velocity is unaffected by the plasma protein. Further, the velocity decreases in the cases where the membrane fluidity (measured by the fatty acid spin label motion in the membrane) decreases.

Bull et al. (1977) have proposed four requirements for analyzing the deformability, i.e., (i) the cell must be held, (ii) the stretching or compressing force must be controlled, (iii) the precise way for measuring deformation must be established, and (iv) the stress must preferably be applied uniaxially. Our present technique fulfills the requirements (ii) and (iv), but does not satisfy (i) and (iii), because it determines the kinetic properties but not the static quantities.

In this connection, EVANS and LA CELLE (1975) have discussed two types of the micropipette aspiration techniques. One determines the negative pressure 
Table 5. Properties of the ACD-preserved blood.

\begin{tabular}{|c|c|c|c|}
\hline & Fresh cells & Preserved cells ${ }^{\mathrm{a}}$ & \\
\hline "Velocity" & $1.00 \pm 0.08$ & $0.75 \pm 0.06$ & Normalized values \\
\hline Osmotic fragility & $0.356 \%$ & $0.358 \%$ & $\% \mathrm{NaCl}$ at $50 \%$ hemolysis $^{b}$ \\
\hline Membrane fluidity $\left(\tau_{\mathrm{c}}\right)^{\mathrm{c}}$ & $1.92 \times 10^{-9} \mathrm{sec}$ & $1.99 \times 10^{-9} \mathrm{sec}$ & Spin label $\mathrm{I}(1,14)$, at $39^{\circ} \mathrm{C}$ \\
\hline Membrane fluidity $(S)^{\mathrm{c}}$ & 0.590 & 0.582 & Spin label $\mathrm{I}(5,10)$, at $39^{\circ} \mathrm{C}$ \\
\hline $\mathrm{O}_{2}$ affinity $\left(P_{50}\right)^{\mathrm{d}}$ & $23.7 \mathrm{mmHg}$ & $18.2 \mathrm{mmHg}$ & $\mathrm{CO}_{2}$-depleted, at $37^{\circ} \mathrm{C}$ \\
\hline $2,3-\mathrm{DPG}$ & $6.2 \mathrm{~mm}$ & $0.95 \mathrm{~mm}$ & Per liter of packed cells \\
\hline (2, 3-DPG/Hb ratio) & 1.16 & 0.19 & Molar ratio \\
\hline ATP & $0.97 \mathrm{~mm}^{\mathrm{e}}$ & 0.64 & Per liter of packed cells \\
\hline $\mathrm{pH}_{\mathrm{i}}^{\mathrm{f}}$ & 7.21 & 6.91 & At $37^{\circ} \mathrm{C}$ \\
\hline
\end{tabular}

a Preserved as ACD blood for 16 days at $4^{\circ} \mathrm{C}$.

b The values obtained by our method (MAEDA et al., 1977) are systematically smaller than those obtained by the classical method (PARPART et al., 1947).

c Calculated as in Table 4.

d Measured as in Table 4. $\mathrm{pH}$ of the suspended solution was 7.40.

e The ATP content of this particular red cells (taken from T. S.) was always smaller than the others.

f Intracellular $\mathrm{pH}$ of the red cells. During the $P_{50}$ measurement, however, $\mathrm{pH}_{\mathrm{i}}$ was 7.20 for both samples, being suspended in the isotonic solution ( $\mathrm{pH} 7.40)$.

required to aspirate the membrane at distance about equal to the radius of the orifice (as a bulge) keeping the biconcavicity of the cell (denoted as $P$-measurement), like the situation at $t=t_{1}$ in Fig. 2. The other determines the relation between the pressure and the length of the finger (or tongue) and/or the shape of the hemispherically deformed cell (denoted as $D$ - and $P_{t}$-measurements), like the shape at $t=t_{2}$ in Fig. 2. The present method is concerned with the time course during $t_{1}<t<t_{2}$, keeping the biconcave shape most of the time. Therefore, as pointed out by EVANS and LA CELLE (1975), the parameter "velocity" reflects the stretch resistance of the membrane. In addition, the length of the finger and the shape change are small, thus the contribution of the water leakage from the cell (JAY and CANHAM, 1977) may be neglected.

The empirical equation, $v \propto\left(\pi R^{2}\right) \cdot(\Delta P) \cdot($ "def"), may be derived as described in APPENDIX, if it is assumed that (i) the increasing rate of the aspirated membrane mass is directly proportional to the increasing rate of the electric resistance $(=$ the decreasing rate of the electric current) due to an increase of the contact surface area between the micropipette wall and the cell surface, and (ii) the contributions from the variation of the density and viscosity of cell content are negligible. The following theoretical equation is obtained:

$$
v=\left(\pi R^{2}\right) \cdot(\Delta P) / \beta^{\prime} E,
$$

where $v$ is the "velocity," $R$ is the radius of the pipette orifice, $\Delta P$ is the negative pressure, $E$ is the Young's modulus of the membrane and $\beta^{\prime}$ is a constant. Therefore, one may compare the ratio of the Young's modulus of two samples using 
the same micropipette at the same pressure (i.e., at constant $R$ and $\Delta P$ ), by the relation

$$
v_{1} / v_{2}=E_{2} / E_{1} .
$$

We must admit that our theoretical consideration, shown in APPENDIX, is rough and neglects some important factors, such as the hemoglobin concentration or the internal viscosity. However, even if the above assumptions are not valid, the "velocity" still represents the "easiness" of the red cell to enter a small orifice, which is primarily correlated with the membrane stretching and/or bending.

The "passage time", i.e., the time to pass through the tip portion of the micropipette, may give another measure for the "easiness" of the cell passage through the capillary in vivo. In general, the passage times prolong, as the velocities decrease. However, it is known that the passage times in a narrow capillary are primarily dependent on the cell volume. The enormous prolongation observed with the glutaraldehyde pretreated cells suggests that the passage times are influenced by the resistance to deform from the biconcave to hemisphere shape and/or by the ability of the water leakage during the passage (JAY and CANHAM, 1977) and by the resistance due to the friction between the micropipette wall and the cell surface. On the other hand, the "velocity" will not be affected by the water leakage nor by the friction. Further, no simple relation can be established between the "passage times" and the pressure, the orifice radius, temperature, etc. Therefore, the "passage times" in the present technique seem to be much more complicated measure, compared with the "velocities," although the former measure may reflect the real capillary passage time. In addition, the "velocity" and the membrane fluidity (measured by the motion of the fatty acid spin labels) seem to be closely related.

Factors influencing the deformability. The red cell deformability will be affected by many factors, as pointed out in the review (CHIEN, 1975), such as (i) the density and viscosity of the cell contents, (ii) the "flexibility," "fluidity," "compressibility" or "Young's modulus" of the membrane (which are undefined, complex function of the states of membrane proteins, phases of the lipid bilayer, protein-lipid interaction, metal ion-membrane interaction, etc.), and (iii) red cell shape. However, it is not certain how these physical and morphological factors are related with the biochemical quantities and modulate the physiological functions (such as blood viscosity, easiness of capillary passage, mechanical strength, etc.). Therefore, the effect of a few variables on the deformability ("velocity") is studied.

a) Temperature: as the temperature is lowered, the velocity decreases, and the double reciprocal plot of $v$ and $T$ gives a straight line (Fig. 4).

Williamson et al. (1975) have shown, by monitoring the fluid shear stressdependent deformation, that red cell deformability increases gradually between $2^{\circ}$ and $24-37^{\circ} \mathrm{C}$ and dramatically between $48^{\circ}$ and $50^{\circ} \mathrm{C}$. Concerning the lipid 
phase of human red cell, particularly for the cells from the same blood donor as studied here, the spin label motion in the membrane gradually increased with temperature up to $40^{\circ} \mathrm{C}$ without distinct phase transition (SHIGA et al., 1977), but irreversibly changes above $40^{\circ} \mathrm{C}$. These facts are consistent with the present results: as temperature is increased, the membrane fluidity increases and the internal viscosity decreases, thus the deformability increases.

b) Cell hardening: the effect of glutaraldehyde and aldehyde treatment on the rheological behavior and the cell deformability has been studied (SCHMID-SCHÖNBEIN et al., 1969; BULL and BRAILSFORD, 1975; MEL and YEE, 1975). The red cells pretreated with higher concentrations of glutaraldehyde (above $0.03 \%$, incubated $30 \mathrm{~min}$ at $0^{\circ} \mathrm{C}$ ) never enter into the narrow micropipette. The cross-linkage of the membrane proteins has been proved (STECK, 1972), and the irreversible immobilization of fatty acid spin labels has been shown (SHIGA et al., 1977), further penetrated glutaraldehyde modifies the state of hemoglobin (Morel et al., 1971). Actually, we could prove the presence of polymerized hemoglobin in the hemolysate of $0.01 \%$ glutaraldehyde pretreated cells, by the molecular sieving technique. All of these factors, i.e., hardening of membrane and hemoglobin polymerization, contribute to the decreased "velocity" observed for the glutaraldehyde pretreated cells, although the cell shapes are unchanged.

In addition, the decreased "velocity" has been demonstrated with the cholesterol-rich human red cells, in which the spin label motion decreases correspondingly to the cholesterol contents in the membrane because of the rigidifying effect of cholesterol (SUDA et al., 1978).

c) Cell aging: the in vivo aging of the red cells affects the "velocity" considerably. LA Celle et al. (1972) have shown that the old cells require the more negative pressure for cell deformation in their cell aspiration experiments. As can be seen in Table 4, many age-dependent factors must be taken into account for the decreased deformability, such as the changes in metabolic activities (reflected to ATP and 2,3-DPG contents), in membrane components and in inorganic ions. An increased oxygen affinity is observed in the old cells, probably due to the reduction of 2,3-DPG. Therefore, the oxygen transport function of the in vivo aged cells decreases, in terms of their increased oxygen affinity and of their decreased ability to pass through the narrow capillaries.

The decreased deformability of the ACD-preserved cells, detected by the present technique, agrees with the earlier observation (WEED et al., 1969; LA CELLE, 1969; WEED, 1970). The difference of the "velocity" between fresh and preserved cells (Table 5) results from the cell shape alteration, due to the decrease in ATP and ion contents, and from the loss of the membrane lipids (reflected to the decreased spin label motion) in the preserved cells (RAPOPORT, 1947; HARADIN et al., 1969; WEED et al., 1969). Further, the increased oxygen affinity, mainly due to the reduction of 2,3-DPG, is observed, as demonstrated by ÅKERBLOM et al. (1968) and BunN et al. (1969). Therefore, the functions of the in vitro aged 
cells are considerably impaired.

The decreased "velocity," observed with the in vivo and in vitro aging by the present technique, coincides with the decreased deformability shown by other methods and corresponds to the decreased membrane fluidity detected by the spin label method. However, it is hard to weigh the determinant factor(s) for the deformability and fluidity as discussed elsewhere (SHIGA et al., 1979).

\section{APPENDIX}

In order to give a qualitative explanation of the empirical equation, $v \propto\left(\pi R^{2}\right)$. $(\Delta P) \cdot(" d e f ")$, the following treatment may throw light on the problem. The relation can be formulated on the basis of the equation of motion, during the aspiration process of $t=t_{1}$ to $t_{2}$ in Fig. 2 .

The shape of the aspirated portion of cell at $t=t_{1}$ (dotted line) and $t_{2}$ (solid line) are shown in Fig. 5. It is clear from the experiments that the longer the finger length the lesser electric current: as increasing the aspirated membrane area, $S(t)$, the length of the contact surface between the inner wall of the micropipette and the cell membrane, $l(t)$, increases, and the electric resistance increases; the time course of electric resistance is determined as $v$.

In the range of $t_{1}<t<t_{2}$, the equation of motion, [force $=d$ (momentum)/ $d t$, can be expressed as follows.

Firstly, the forces applied to the red cell membrane are (i) the force from the inside of the cell . . $\pi(R-r)^{2} P_{0}=\pi R^{2} \cdot P_{0}$ (as $R \gg r$ ), where $R$ is the radius of the micropipette orifice, $r$ is the thickness of the membrane, and $P_{0}$ is the internal pressure of the cell,

(ii) the force from the outside of the cell $\ldots \pi R^{2} \cdot\left(\Delta P-P_{0}\right)$, where $\Delta P$ is the applied negative pressure,

(iii) the force along the line $\mathrm{AB}$, of which the direction is opposite to $\mathrm{OX} \ldots-F$. Therefore, the total forces, (i) + (ii) + (iii), are ... $\pi R^{2} \cdot \Delta P-F$.

Secondly, the momentum of the aspirated membrane is $\ldots . S(t) \cdot r \cdot \rho \cdot(d x)$ $d t$ ), where $x$ is the distance between the center of orifice $(\mathrm{O})$ and the center of gravity

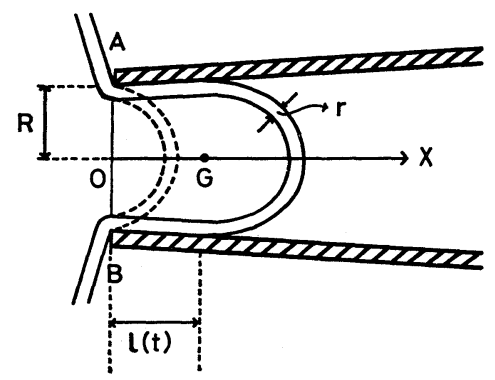

Fig. 5. Scheme of the red cell aspirated into the micropipette tip. 
of the aspirated membrane (G), and $\rho$ is the density of the membrane. Therefore, the equation of motion becomes

$$
\pi R^{2} \cdot \Delta P-F=\frac{d}{d t}\left[S(t) \cdot r \cdot \rho \cdot \frac{d x}{d t}\right] \text { or } r \cdot \rho \cdot\left[\frac{d S(t)}{d t} \cdot \frac{d x}{d t}+S(t) \cdot \frac{d^{2} x}{d t^{2}}\right] .
$$

Here $d x / d t$ can be approximated to $d l(t) / d t$ and proportional to the empirical parameter, "velocity (v)," which is constant at $t_{1}<t<t_{2}$, thus $d^{2} x / d t^{2}=0$. Also, $d S(t) / d t=2 \pi R \cdot d l(t) / d t$, thus $[d S(t) / d t] \cdot[d x / d t]=2 \pi R \cdot[d l(t) / d t]^{2}$. As the order of $d l(t) / d t$ is about $1 \mu \mathrm{m} / 0.1 \mathrm{sec}\left(i . e ., 10^{-3} \mathrm{~cm} \cdot \mathrm{sec}^{-1}\right), \Delta P \gg[d S(t) / d t] \cdot[d x / d t]$.

Finally, the equation of motion may be approximated to

$$
\pi R^{2} \cdot \Delta P=F \text {. }
$$

For the force $F$, we consider (i) the friction between the glass edge and the membrane,

$$
F_{1}=\alpha \cdot \mu,
$$

where $\mu$ is the frictional coefficient and the constant $\alpha$ is assumed to be independent of $v$, and (ii) the bending elasticity of the membrane, which is proportional to the couple of forces for bending (i.e., the Young's modulus, $E$, of the membrane),

$$
F_{2}=\beta \cdot E \cdot i
$$

where $i \propto v$, and $\beta$ is a constant. Thus replacing $\beta \cdot i$ by $\beta^{\prime} \cdot v$,

$$
F_{2}=\beta^{\prime} \cdot E \cdot v \text {. }
$$

We obtain the equation

$$
\alpha \cdot \mu+\beta^{\prime} \cdot E \cdot v=\pi R^{2} \cdot \Delta P .
$$

Since $v \propto\left(\pi R^{2}\right) \cdot(\Delta P) \cdot($ "def") experimentally, $\alpha \cdot \mu$ must be small, thus we finally obtain

$$
v=\pi R^{2} \cdot \Delta P \cdot \frac{1}{\beta^{\prime} \cdot E}
$$

The equation (2) fits the empirical equation (1).

It should be noted that the equation could be derived by neglecting the contribution of the intracellular components (e.g., the internal viscosity) or of the membrane properties (e.g., the compressibility, etc.). Therefore, the equation must be considered as a first approximation.

This work was supported by grants from the Ministry of Education, Science and Culture of Japan and from the Medical Foundation of Ehime.

\section{REFERENCES}

Abraham, E. C., Walker, D., Gravely, M., and Huisman, T. H. J. (1975) Minor hemoglobins in sickle cell anemia, $\beta$-thalassemia and related conditions: A study of red cell fractions 
isolated by density gradient centrifugation. Biochem. Med., 13: 56-77.

Åkerblom, O., DE Verdier, C. H., GARBY, L., and Högman, C. (1968) Restoration of defective oxygen transport function of stored red blood cells by addition of inosine. Scand. J. Clin. Lab. Invest., 21 : 245-248.

AXel, F. S. (1976) Biophysics with nitroxyl radicals. Biophys. Struct. Mech., 2: 181-218.

BRAASCH, D. (1971) Deformability and traversing time of shape-transformed single red cells passing through a $4 \mu$ glass-capillary. Pflügers Arch., 329: 167-171.

Bull, B. S. and Brailsford, J. D. (1975) A new method of measuring the deformation of the red cell membrane. Blood, 45: 581-586.

Bull, B. S., Brailsford, J. D., and Korpman, R. A. (1977) Red cell membrane deformability: An examination of two apparently disparate methods of measurement. Blood Cells, 3: 39-54.

Bunn, H. F., May, M. H., Kocholaty, W. F., and Shields, C. E. (1969) Hemoglobin function in stored blood. J. Clin. Invest., 48: 311-321.

CHIEN, S. (1975) Biophysical behavior of red cells in suspensions. In: The Red Blood Cells, 2nd ed., Vol. II, ed. by Surgenor, D. M. Academic Press, New York, pp. 1031-1133.

Enoki, Y., Tomita, S., Maeda, N., Kawase, M., and Okuda, T. (1972) A simple method for determination of red cell intracellular pH. J. Physiol. Soc. Jpn., 34: 761-762.

ERnandez, J. R., Schreier, S., and Chaimovich, H. (1976) Spin label studies of micellar and pre-micellar aggregates. Chem. Phys. Lipids, 16: 19-30.

Evans, E. A. (1973) New membrane concept applied to the analysis of fluid-shear and micropipette-deformed red blood cells. Biophys. J., 13: 941-954.

Evans, E. A. and LACELle, P. L. (1975) Intrinsic material properties of the erythrocyte membrane indicated by mechanical analysis of deformation. Blood, 45: 29-43.

HARADIN, A. R., WEED, R. I., and REED, C. F. (1969) Changes in physical properties of stored erythrocytes, relationship to survival in vivo. Transfusion, 9: 229-237.

Hegner, D., Schummer, U., and Schnepel, G. H. (1973) The interaction of a lytic peptide, melittin, with spin labeled membranes. Biochim. Biophys. Acta, 291: 15-22.

Hubbel, W. L. and MCConnell, H. M. (1971) Molecular motion in spin labeled phospholipids and membranes. J. Am. Chem. Soc., 93: 314-326.

Imai, K., Morimoto, H., Kotani, M., Watari, H., Hirata, W., and Kuroda, M. (1970) Studies on the function of abnormal hemoglobins. I. An improved method for automatic measurement of oxygen equilibrium curve of hemoglobin. Biochim. Biophys. Acta, 200: 189-196.

$\mathrm{J}_{\mathrm{AY}}$, A. W. L. (1973) Viscoelastic properties of the human red blood cell membrane. I. Deformation, volume loss, and rupture of red cells in micropipette. Biophys. J., 13: 1166-1182.

JAY, A. W. L. and CANHAM, P. B. (1977) Viscoelastic properties of the human red blood cell membrane. II. Area and volume of individual red cells entering a micropipette. Biophys. J., 17: 169-178.

LACELLE, P. L. (1969) Alteration of deformability of the erythrocyte membrane in stored blood. Transfusion, 9: 238-248.

LaCelle, P. L., Kirkpatrick, F. H., Udkow, M. P., and Arkin, B. (1972) Membrane fragmentation and $\mathrm{Ca}^{++}$-membrane interaction: Potential mechanisms of shape change in the senescent red cell. Nouv. Rev. Fr. Hematol., 12: 789-798.

Maeda, N., Chang, H., Benesch, R., and Benesch, R. E. (1971) A simple enzymatic method for the determination of 2,3-diphosphoglycerate in small amounts of blood. New Engl. J. Med., 284: 1239-1242.

Maeda, N., Aono, K., Sekiya, M., Suda, T., and Shiga, T. (1977) A computerized method for the determination of the osmotic fragility curve of erythrocytes. Anal. Biochem., 83: 149-161.

MeL, H. C. and YeE, J. P. (1975) Erythrocyte size and deformability studies by resistive pulse 
spectroscopy. Blood Cells, 1: 391-399.

Mitchison, J. M. and Swann, M. M. (1954) The mechanical properties of the cell surface. 1. The cell elastometer. J. Exp. Biol., 31: 443-460.

Morel, F. M. M., BAKer, R. F., and WaYland, H. (1971) Quantitation of human red blood cell fixation by glutaraldehyde. J. Cell Biol., 48: 91-100.

Parpart, A. K., Lorenz, P. B., Parpart, E. R., Gregg, E. R., and Chase, A. M. (1947) The osmotic resistance (fragility) of human red cells. J. Clin. Invest., 26: 636-640.

Rand, R. P. and Burton, A. C. (1964) Mechanical properties of the red cell membrane. I. Membrane stiffness and intracellular pressure. Biophys. J., 4: 115-135.

RAND, R. P. (1964) Mechanical properties of the red cell membrane. II. Viscoelastic breakdown of the membrane. Biophys. J., 4: 303-316.

RAPOPORT, S. (1947) Dimensional, osmotic and chemical changes of erythrocytes in stored blood. I. Blood preserved in sodium citrate, neutral and acid citrate-glucose (ACD) mixtures. J. Clin. Invest., 26: 591-615.

Schlick, W. and Schmid-SchönBein, H. (1975) Measurement of single red cell deformability: Preliminary report. Blood Cells, 1: 333-338.

Schmid-Schönbein, H., Wells, R., and Goldstone, J. (1969) Influence of deformability of human red cells upon blood viscosity. Circ. Res., 25: 131-143.

SCHMID-SchönBeIN, H. (1976) Microrheology of erythrocytes, blood viscosity, and the distribution of blood flow in the microcirculation. In: Cardiovascular Physiology II, ed. by Guyton, A. C. and Cowley, A. W. University Park Press, Baltimore, pp. 1-62.

Shiga, T., Shiga, K., and Kuroda, M. (1971) An on-line differential converter for obtaining the first derivative of absorption spectra. Anal. Biochem., 44: 291-297.

Shiga, T., SudA, T., and MAEdA, N. (1977) Spin label studies on the human erythrocyte membrane: Two sites and two phases for fatty acid spin labels. Biochim. Biophys. Acta, 466: 231-244.

Shiga, T., Maeda, N., Suda, T., Kon, K., and Sekiya, M. (1979) The decreased membrane fluidity of in vivo aged, human erythrocytes: A spin label study. Biochim. Biophys. Acta, 533: 84-95.

STECK, T. L. (1972) Cross-linking the major proteins of the isolated erythrocyte membrane. J. Mol. Biol., 66: 295-305.

Stone, T. J., Buckman, T., Nordio, P. L., and McConnell, H. M. (1965) Spin labeled biomolecules. Proc. Natl. Acad. Sci. U. S., 54: 1010-1017.

Stoltz, J. F. and Vigneron, C. (1976) Viscosité sanguine et déformabilité des hématies, Lab. Hoechst, Paris, pp. 37-51.

Suda, T., Maeda, N., Sekiya, M., Natsuoka, K., Tokita, R., and Shiga, T. (1978) Influences of membrane cholesterol on the human red cell properties. Med.J. Osaka Univ., 29: 21-27.

Teitel, P. (1967) Le test de la filtrabilité érythrocytaire. Nouv. Rev. Fr. Hematol., 7: 195-214.

VAn Assendelft, O. W. (1970) Spectrophotometry of Hemoglobin Derivatives, Royal VanGorcum, Assen, p. 83.

Weed, R. I., LA Celle, P. L., and Merril, E. W. (1969) Metabolic dependence of red cell deformability. J. Clin. Invest., 48: 795-809.

WeED, R. I. (1970) The importance of erythrocyte deformability. Am. J. Med., 49: 147-150.

Williamson, J. R., Shanahan, M. O., and Hochmuth, R. M. (1975) The influence of temperature on red cell deformability. Blood, 46: 611-624. 